\title{
DEVELOPMENT OF FIBER RICH RICE BASED BISCUIT
}

\author{
Fernando P.A.T. ${ }^{1 *}$, Thilakarathne B.M.S.K. ${ }^{2}$, Mahindarathna M.G.P.P. ${ }^{1}$ and \\ Subodinee. A.A.M ${ }^{1}$ \\ ${ }^{1}$ Uva Wellassa University, Passara road, Badulla, Sri Lanka \\ ${ }^{2}$ Institute of Post Harvest Technology, Jayanthi Mawatha, Anuradhapura, Sri Lanka
}

\begin{abstract}
A study was carried out on the utilization of banana blossom in the nutritional enrichment of biscuits. Blossom of the banana plant (Musa paradisiaca) is an excellent source of crude fiber in the human diet. Consumption of dietary fiber is known to lower blood cholesterol level, normalize blood glucose levels, promote laxation, lower the risk of colon cancer and breast cancer. Banana blossom was processed into flour by dehydration followed by powdering. Pretreatment was carried out prior to the dehydration. Resulted powder was consist of $14.54 \%$ of crude fiber. Low moisture gain and a less color change in product packed in Polyethylene (150 gauge) were observed during storage for four weeks in comparison to the product packed Polypropylene (150 gauge). Banana blossom flour used to supplement rice flour, in the percentages of $0,3,5,10$, and 15 for biscuit production. The proximate composition, sensory evaluation and microbiological quality, in terms of Total Colony Count were evaluated. The crude fiber and fat contents $(\%)$ increased with increase in the proportion of banana blossom flour level, with the $15 \%$ banana blossom flour having the values of 12.32 and 19 respectively. Lowest values of $2.93,2.40$, and 8.35 and 55 were observed for the biscuit with $15 \%$ banana blossom flour level in terms of crude protein, ash, moisture and carbohydrate respectively, showing decrease with corresponding increase in the banana blossom flour levels. The microbiological analysis indicated that the Total Colony ranged between $1.00 \mathrm{cfu} / \mathrm{g}$ and $1.75 \mathrm{cfu} / \mathrm{g}$ was observed during the extended shelf life analysis in product packed in Aluminum foil laminated with high density polyethylene (Al/HDPE) in comparison to product packed in polyethylene. Sensory evaluation showed that banana blossom supplemented biscuits were not significantly different $(\mathrm{p}<0.05)$ from whole wheat biscuits with respect to sensory attributes of texture, color, taste and overall acceptability, at $15 \%$ level banana blossom flour supplementation.
\end{abstract}

Keywords : Banana Blossom, Fiber, Biscuit, Rice Flour

\section{Introduction}

The project was selected in aim of, developing a food product utilizing locally available raw materials. The main ingredients of this product are Rice flour and Banana blossom flour. These two ingredients were selected because there is a renewed interest in trying to promote rice consumption in Sri Lanka due to the huge drain in foreign exchange to import wheat flour. In addition, Banana blossom is a relatively underutilized source of cheap vegetable fiber presently relished by rural folk and the importance of fiber in our daily diet is becoming apparent to the urban population as well.

Development of a biscuit substituting Rice flour for wheat flour and enriching the product with banana blossom fiber to improve its health benefits while trying to keep the costs barest level possible, so that the common man can enjoy the benefits of this nutritious ready to eat product. Some attempts have already been made to utilize the banana blossom by dehydration and preservation as a dehydrated vegetable. Under this study also the techniques adopted in dehydration were used in order to produce flour suitable for the development of the product i.e a biscuit. Which unlike a dehydrated vegetable will appeal to a wider consumer base. 
Using Rice flour in confectionary poses some problems not found in the use of wheat flour. This is mainly due to the absence of Gluten which is a protein in rice flour as compared to wheat flour. Attempts have been taken to maximize the use of rice flour in the developed product, still maintaining all the desirable characteristics of a biscuit, like color, texture, taste, and overall acceptability and enhancing its nutritional quality. This product can be marketed as a functional food as well.

Other biscuits incorporating herbs, finger millet like locally available sources, are well accepted by the consumers, mainly due to its health benefit aspects. Fiber content is significant in consumer preferences for this biscuits. With the additional impetus of using our own rice this product is expected to have considerable market potential. Further development and improvements to this formula are needed before this can be released to the market. Time, financial constraints and limited resources have necessarily limited the study.

\section{Objectives}

\section{Overall objective}

The overall objective of this research is to enhance the local rice consumption via value added rice based products.Promote the intake of fiber rich banana blossom among people.

\section{Specific objectives}

To develop low cost methodology for ready to eat fiber rich rice based biscuit.

To determine the nutritional value, shelf life and the production cost of biscuits.

\section{Materials and Methodology}

\section{Development and formulation of fiber rich rice based biscuit}

This study was conducted at The Institute of Post Harvest Technology (IPHT), Jayanthi Mawatha , Anuradhapura from $17^{\text {th }}$ of February to $30^{\text {th }}$ of July 2010.

\section{Materials}

All the materials like Rice flour, Sugar, Margarine, Ginger flavor, Egg yolk, Baking powder, which were required for the development of the product, were purchased from local market except banana blossom. Evenly mature banana blossom of the cv. Sini /Musa paradisiacai(an extensively grown cultivar in Sri Lanka) were procured from the fruit orchards of the IPHT. The banana blossom were snapped off leaving $15 \mathrm{~cm}$ long part in the distal end of the fruit bunch after cessation of fruit formation on the banana bunch.

\section{Procedure}

\section{Preliminary study for the preparation of banana blossom flour}

Since limited studies have previously been reported, preliminary studies were carried out to establish basic processing methods prior to commencing the main study. Outcomes of these methods were selected for later testing and processing. In a systematic manner, thickness of the banana blossom slices, measure to avoid browning of cut slices and processing temperature- time requirement to develop a product that has acceptable color after dehydration.

Four sizes of thickness of slices (viz 3, 4, 5 and $6 \mathrm{~mm}$ ) were tested to determine the most appropriate thickness that gives an attractive product after processing. Among the four thicknesses of the banana blossom, $6 \mathrm{~mm}$ slices 
were found too thick and not good in texture and appearance curled and twisted. Slices of $3 \mathrm{~mm}$ thickness showed least changes in appearance, and hence it was selected.

Since the banana blossom develops a dark brown color when sliced and later added to water. In this study slicing was directly done in to separate solutions, namely hot water(at $96-98^{\circ} \mathrm{C}$ for 3-4 minutes), solutions containing table salt, Sodium Metabisulfite and Citric acid, separately.

The results of the preliminary study indicated that hot water blanching at $96-98^{\circ} \mathrm{C}$ for 5 minutes caused a rapid browning giving a dark color to the final dehydrated product, and hence it was not selected for further processing purpose. Pre-treatment with Salt was inferior to Sodium Metabisulfite or Citric acid as the former two substances resulted in the darker dehydrated product. This color will remain in the powdered product as well, and hence it was not selected for further processing purpose. Out of the latter two, Citric acid was selected as pre-treatment due to controversial issues on Sodium Metabisulfite. Citric acid had relatively lower color change than the rest. Out of the concentrations used in the range of $10 \mathrm{~g} / \mathrm{l}$ to $25 \mathrm{~g} / \mathrm{l}$ and $20 \mathrm{~g} / \mathrm{l}$ of Citric acid solution was found effective in minimizing browning, and hence used foregoing experiments.

Furthermore, the optimum temperature for the activity of $20 \mathrm{~g} / \mathrm{l}$ Citric acid solution was determined using four temperatures ( viz. $25^{\circ} \mathrm{C}, 35^{\circ} \mathrm{C}, 45^{\circ} \mathrm{C}$ and $55^{\circ} \mathrm{C}$ ) for 5 minutes and assessing color changes of the dehydrated product. It was found that the activity of Citric acid was better at $55^{\circ} \mathrm{C}$. Three drying temperature $\left(v i z .45^{\circ}, 50^{\circ}\right.$ and $55^{\circ} \mathrm{C}$ ) were tested to determine the most suitable temperature time combination to reduce moisture content in slices. The time taken to reduce moisture content $7 \%$ at 45,50 , and $55^{\circ} \mathrm{C}$ was $24 \mathrm{hrs}, 12 \mathrm{hrs}$ and $8 \mathrm{hrs}$ respectively. The best time- temperature combination for dehydration was $55^{\circ} \mathrm{C}$ for $8 \mathrm{hrs}$.

\section{Dehydration of Banana blossom}

Freshly harvested the banana blossom were washed under running water after removing 3 to 4 outermost fibrous bracts, and fresh weight of the each banana blossom was recorded in order to determine the final yield of the processed product after dehydration. The blossoms were then sliced to a thickness of $3 \mathrm{~mm}$ directly in to $20 \mathrm{gl}^{-}$ Citric acid solution using a vegetable slicer. To fully immerse 250 to $300 \mathrm{~g}$ of the banana blossom slices, 1 liter of $20 \mathrm{gl}^{-}$Citric acid solution was needed. All the core tissues in the slices were then removed while in the solution, and the slices were then removed while in the solution, and slices were left in the solution for another 5 minutes. At the end of 5 minute duration, slices were spread over plastic trays at a loading density of $2.2 \mathrm{~kg} / \mathrm{m}^{2}$ and allowed to drain out excess liquid. Slices were kept at $55^{\circ} \mathrm{C}$ in an oven for $8 \mathrm{hrs}$. At the end of dehydration, the weight of dehydrated product was recorded. Dehydrated banana blossoms were then subjected to powdering process. 


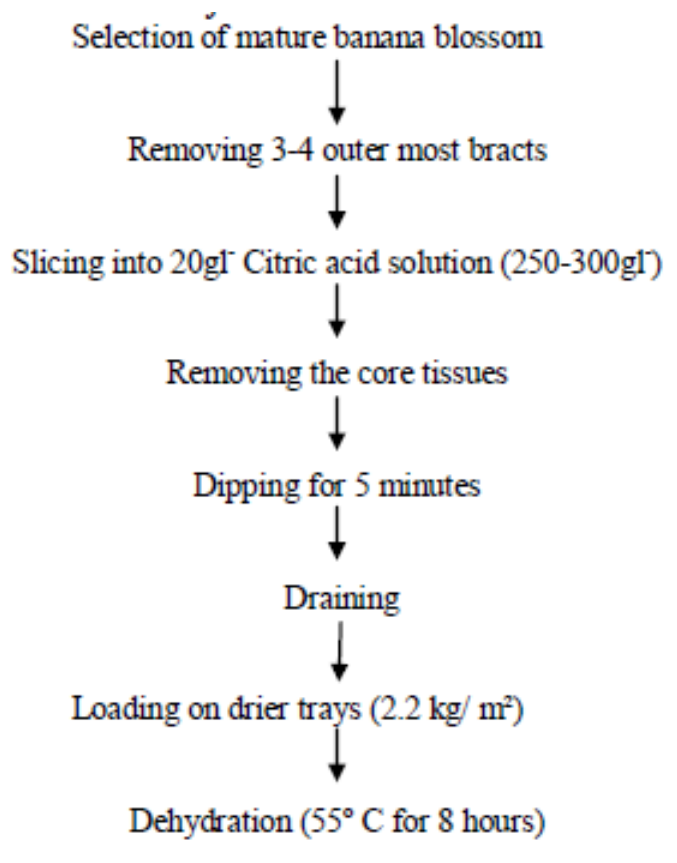

Figure 1 : Processing of Banana blossom flour

Color values of dried samples were measured using a Minolta CR 300, C.M, 2002 Spectrocolorimeter. Color or the extent of browning of the dehydrated product was assessed in terms of $\mathrm{L}$ ' value. The $\mathrm{L}$ value show the lightness and darkness, i.e. zero for opaque to 100 for white color. Moisture content of both dehydrated and fresh the banana blossom was determined by oven drying. The crude protein, crude fiber, total ash and mineral contents of the dehydrated and fresh banana blossom were determined according to the standard methods of $\operatorname{AOAC}(2000)$.

Two sets of the processed product were stored for assessment of physical properties after storage of one month. These two sets were stored separately in $12 \mathrm{~cm}$ in to $9 \mathrm{~cm}$ pouch $(8 \mathrm{~g}$ each) of polypropylene (150 gauges) and polyethylene (150 gauges). The pouches were stored under ambient conditions (i.e. at $30 \pm 2{ }^{\circ} \mathrm{C}$ and $75 \% \mathrm{RH}$ ) for month. At the end of one month storage, the samples were analyzed for moisture content and color ( $\mathrm{L}$ value) as adopted previously. The samples were visually observed for the presence of fungal colonies and color changes, if any.

\section{Determination of proximate composition of Banana blossom flour}

Moisture content was determined using Oven drying method. In addition Ash content, Crude fat, Crude fiber, Crude Protein was analyzed according to the AOAC Official Methods 2000.

\section{Determination of functional properties of Banana blossom flour}

The water absorption capacity was determined according to Rossario and Flores, (1981).

\section{Development process of fiber rich rice based biscuit}

The formulation included Rice flour $300 \mathrm{~g}$, sugar $100 \mathrm{~g}$, margarine $75 \mathrm{~g}$, baking powder $2.5 \mathrm{~g}$, ginger flavor $5 \mathrm{ml}$, one egg and milk (10-20) $\mathrm{ml})$. 
Flour blend was sieved together with baking powder. In a separate container, Margarine, Vanilla and egg were mixed until becomes a whitish, cream. The flour content was added into liquid mixture and mixed again. Then, milk (10-20 ml) was added in requisite volume (which was required for the kneading) the mixture was kneaded into stiff dough. The dough was rolled on a sheeting board to a sheet of uniform thickness of about $4 \mathrm{~mm}$ by using a rolling pin. Cutting of biscuits was done by using a biscuit cutter. The biscuit cuts were placed on a lightly greased baking tray and baked for 15 minutes at $165^{\circ} \mathrm{C}$. The baked biscuits were allowed to cool, packed and stored.

Rice flour biscuits without banana blossom flour were also prepared as control biscuits for the study. Treatments were as below;

\section{Rice flour,( g) Powdered Banana blossom,(g)}

$\begin{array}{ll}300 & 0 \\ 291 & 9 \\ 285 & 15 \\ 270 & 30 \\ 255 & 45\end{array}$

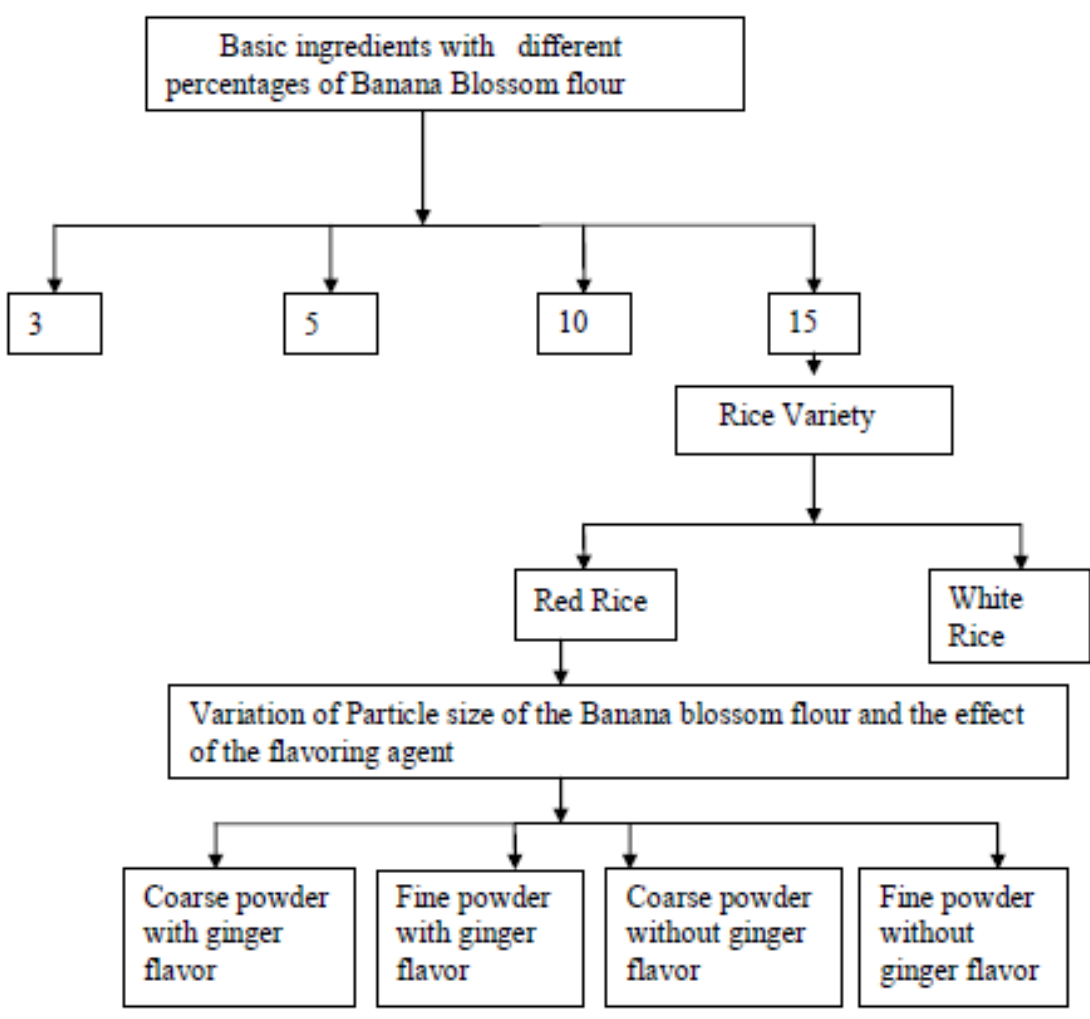

Figure 2: Experiments carried out 


\section{Proximate analysis}

The proximate composition of the banana blossom supplemented biscuit samples was determined using the official methods of AOAC (2000). The samples were analyzed for moisture, ash, crude fiber, crude protein, crude fat and carbohydrate.

\section{Storage study of the developed biscuit}

Storage studies were carried out with Banana blossom flour incorporated biscuit which was selected from the sensory analysis, as the optimum acceptable level.

Packaging materials were polypropylene (150 gauges) and Aluminum foil laminated with high density polyethylene. Baked biscuits were kept on a wire rack till they reach the room temperature. Biscuits (100g) were filled in $105^{*} 165 \mathrm{~mm}$ size pouches made using above packaging materials. Packets were heat sealed and kept under ambient conditions. They were withdrawn at regular intervals (7 days) and biscuits were analyzed for moisture content, extractable fatty acid.

\section{Shelf life analysis of the developed product}

Acid value was determined by mixing $10 \mathrm{~g}$ of ground biscuit powder, $50 \mathrm{ml}$ of neutral solvent $(25 \mathrm{ml}$ ether +25 $\mathrm{ml} 95 \%$ alcohol $+1 \%$ phenolphthalein) and titrating against $0.1 \mathrm{~N} \mathrm{KOH}$ solution. Phenolphthalein was the indicator (Thimmiah, 1999).

\section{Calculation}

Acid value of the sample $=\underline{\text { titration of sample } * \text { normality of } \mathrm{KOH} * 56.1}$

$$
\text { sample weight }
$$

Total bacterial count and Yeast and Mold count of the developed sample was counted using AOAC, 2000: AOAC Official Method during the storage life. Microsoft Excel 2000 software was used for data analysis of extended shelf life analysis.

\section{Determination of total cost of production}

Total cost of production of one biscuit was calculated including the cost of ingredients, cost of ingredients, cost of fuel, labor cost and cost of packing material.

\section{Results}

\section{Preparation of banana blossom flour}

\section{The $L^{\prime}$ Value}

The decrease in the $\mathrm{L}^{\prime}$ value indicates an increase in brown color development, which finally develops a dark brown color in the biscuit. The brown color development in plant tissues occurs due to activities of enzymes. In particular, the formation of brown pigments is developed when PolyPhenol Oxidase enzyme (PPO enzyme) reacts with Phenolic compounds. The L'value (57.66) was found with $20 \mathrm{gl}^{-}$Citric acid at $55^{\circ} \mathrm{C}$ with emersion duration of 5 minutes. When the emersion duration was increased to 30 minutes at the same temperature, the $\mathrm{L}^{\prime}$ value significantly increased to 60.01. The possible reason may be the increased penetration of citric acid into cells and thereby inhibiting the PPO, which otherwise oxidizes Polyphenolic compounds in the banana blossom resulting browning of the end products. 


\section{Chemical Properties}

There were non-significant decrease in crude protein and fiber due to processing of the banana blossoms compared to the fresh blossom. Crude fiber content significantly decreased from $21.31 \mathrm{~g} / 100 \mathrm{~g}$ dry weight in the fresh blossoms to $14.54 \mathrm{~g} / 100 \mathrm{~g}$ dry weight in the processed product.

Table 1: Physico-chemical properties of fresh and dehydrated banana blossom

\begin{tabular}{llll}
\hline Parameter & $\begin{array}{l}\text { Fresh banana } \\
\text { blossoms }\end{array}$ & Dehydrated banana & blossoms \\
\hline & & \\
Moisture (g/ 100g) & 91.16 & 7.596 \\
Crude protein ( g/ 100g of DM) & 20.01 & 4.89 \\
Crude fat ( g/ 100g of DM) & 6.00 & 12.01 \\
Crude fiber ( g/ 100g of DM) & 20.31 & 14.54 \\
Total ash ((g/ 100g of DM) & 8.74 & 19.26 \\
$\mathrm{Ca}(\mathrm{mg} / \mathrm{g}$ of DM) & 3.42 & 2.82 \\
$\mathrm{Fe}(\mathrm{mg} / \mathrm{g}$ of DM) & 0.13 & 0.01 \\
& & \\
\hline
\end{tabular}

\section{Physical properties of banana blossom flour during storage:}

After storage of one month, the dehydrated banana blossoms packed in Polypropylene and Polyethylene were found to gain moisture contents of $1.02 \%$ and $0.81 \%$ respectively based on the moisture content at the time of storage. This indicates superiority of Polyethylene over Polypropylene for storage of the processed banana blossom.

The $\mathrm{L}^{\prime}$ value decreased from 57.66 to 56.00 for the dehydrated banana blossoms stored in pouches made of Polypropylene, while in Polyethylene also, the L' value decrease slightly from 57.66 to 57.00 at the end of the one month storage. In the Polyethylene packing material, there is a higher resistance to moisture, thus lowering the oxidative deterioration. This could be reason for maintaining the moisture free condition of the processed product. These characteristics in Polyethylene would have prevented any deterioration and browning thus retaining the color of the processed product. In these characteristics, Polypropylene packing material appeared to be inferior. Fungal or mold growth were not observed in any of the products packed under different packing materials. 


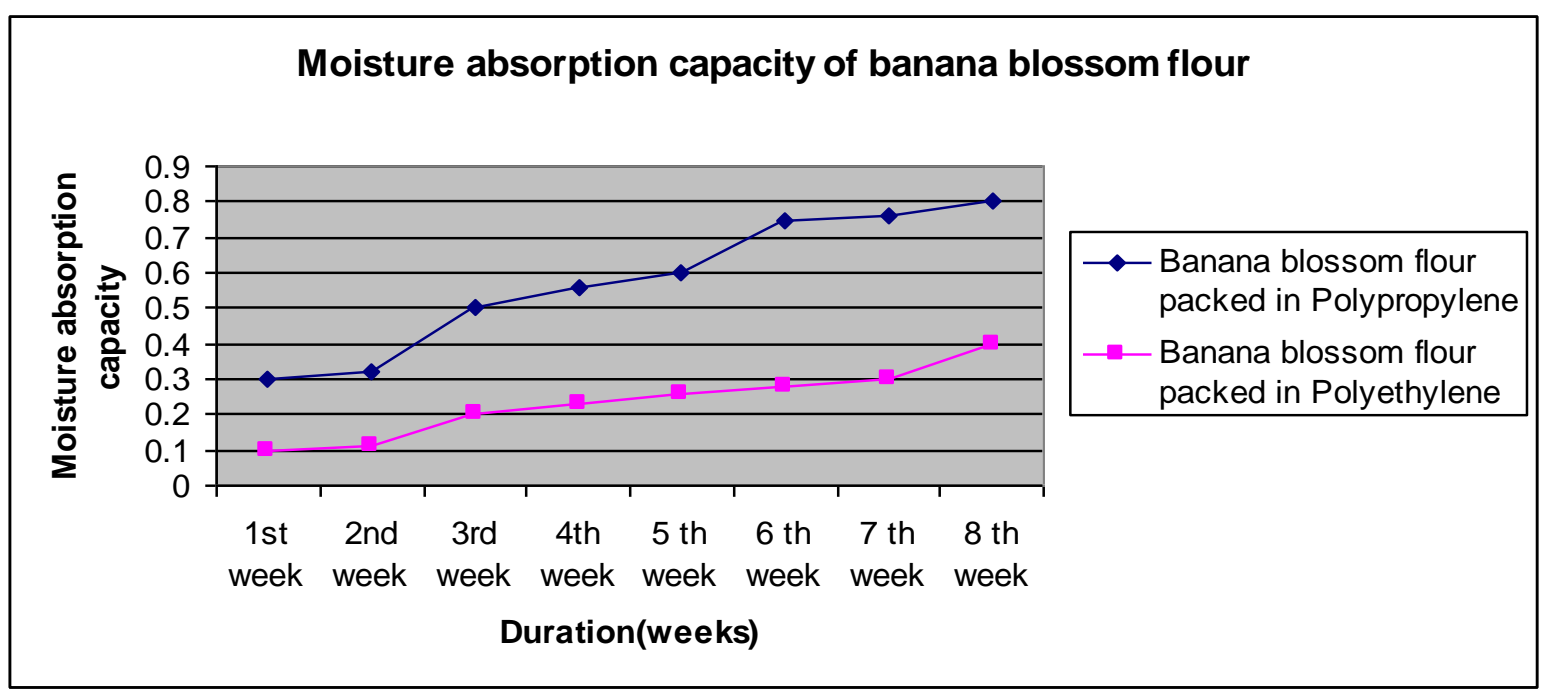

Figure 1 :Moisture Absorption capacity of Banana Blossom Flour

\section{Moisture absorption capacity of banana blossom flour during Storage}

\section{Development and formulation of Fiber rich rice based biscuit}

Fiber rich rice based biscuit can be prepared using Rice flour under household method and the commercialized method. Household method acts as the maximization of under-utilized Banana blossom. Banana blossoms which is remaining after harvesting of banana bunches can be used for the preparation.

Table 2 : Nutritional profile of the developed biscuit

\begin{tabular}{|l|l|l|l|}
\hline $\begin{array}{l}\text { Parameter/ Sample of the biscuit } \\
(\%)\end{array}$ & \multicolumn{1}{|c|}{ A } & B & \multicolumn{1}{|c|}{ C } \\
\hline Protein & 12.50 & 2.88 & 2.93 \\
\hline Ash & 3.09 & 2.3 & 2.40 \\
\hline Moisture & 11.50 & 8.1 & 8.35 \\
\hline Fat & 26.50 & 21 & 19 \\
\hline Fiber & 1.03 & 9.94 & 12.32 \\
\hline Carbohydrate & 45.38 & 55.78 & 55 \\
\hline
\end{tabular}

A-Biscuits produced from $100 \%$ wheat flour

B-Biscuits produced from $15 \%$ fine banana blossom flour with ginger flavor

C-Biscuits produced from $15 \%$ coarse banana blossom flour with ginger flavor

The proximate composition of the whole wheat biscuits and banana blossom supplemented biscuits samples are as presented in Table 2 . The crude protein decreased with increase in the proportion of the banana blossom flour level in the biscuit samples. The highest crude protein $(\%)$ of 12.50 was recorded for the whole wheat biscuits and this value decreased gradually to the lowest value of 2.88 and 2.93 recorded for the biscuits of $15 \%$ fine banana blossom flour and $15 \%$ coarse banana blossom flour respectively. The protein content of wheat has been reported to be higher than its banana blossom flour counterpart and this could be responsible for the lower values of crude proteins in the biscuit samples, as the amount of banana blossom flour increases. (Morton and Miami, 1987;Asiedu, 1989; Udio et al., 2003). 
The crude fiber (\%) ranged between 1.03 and 12.32 and this showed a corresponding increase with increase in the proportion of banana blossom flour. There is a significant impact of particle size of the banana blossom flour towards the fiber content of the final product. Banana blossom has relatively higher crude fiber than wheat and this could justify the result obtained for the different biscuit samples. Crude fiber is known to aid the digestive system of human (Ihekoronye and Ngoddy, 1985). This indicates that the Fiber rich rice based biscuits could attract good acceptability by many people as well health organizations. Fibers act as fillers and as such they interrupt the gluten structure in developed doughs. It is thus more difficult to achieve the same degree of open texture in biscuits and crackers with added fiber compared with those made with white rice flour or no added fiber.

The fat content $(\%)$ of the biscuits followed the same trend with crude protein, though the incremental values were minimal. The highest value of 26.50 was recorded for the whole wheat biscuits while lowest value of $19 \%$ was obtained for the $15 \%$ coarse banana blossom flour biscuits. Fat plays a significant role in the shelf life of food products and as such relatively high fat content could be undesirable in baked food products. This is because fat can promote rancidity in foods, leading to development of unpleasant and odorous compounds (Ihekoronye and Ngoddy, 1985). The moisture contents of the biscuits ranged between $8.1 \%$ and $11.5 \%$, with the whole wheat biscuits having the highest value. This retards the microbial infestations of the product. The carbohydrate contents were highest for the biscuits in terms of all proximate composition parameters ( crude protein, crude fiber, fat, ash, moisture ) determined in this study. This was expected as the ingredients composed of mainly carbohydrate rich materials, which are rice flour, banana blossom flour, sugar etc.

\section{Shelf life study of the developed product}

Microorganisms play significant role in the determination of shelf lives of food products. They are usually responsible for spoilage of many food items. A high Total Colony Count could indicate the presence mixed population of microorganisms, which may consist of spoilage types. Limits of microbial counts have been recommended in most foods to keep them safe for consumption (Porter, 1978). The product should however be well kept after processing in suitable packaging materials capable of preventing contamination and hence subsequent proliferation of spoilage microorganisms.

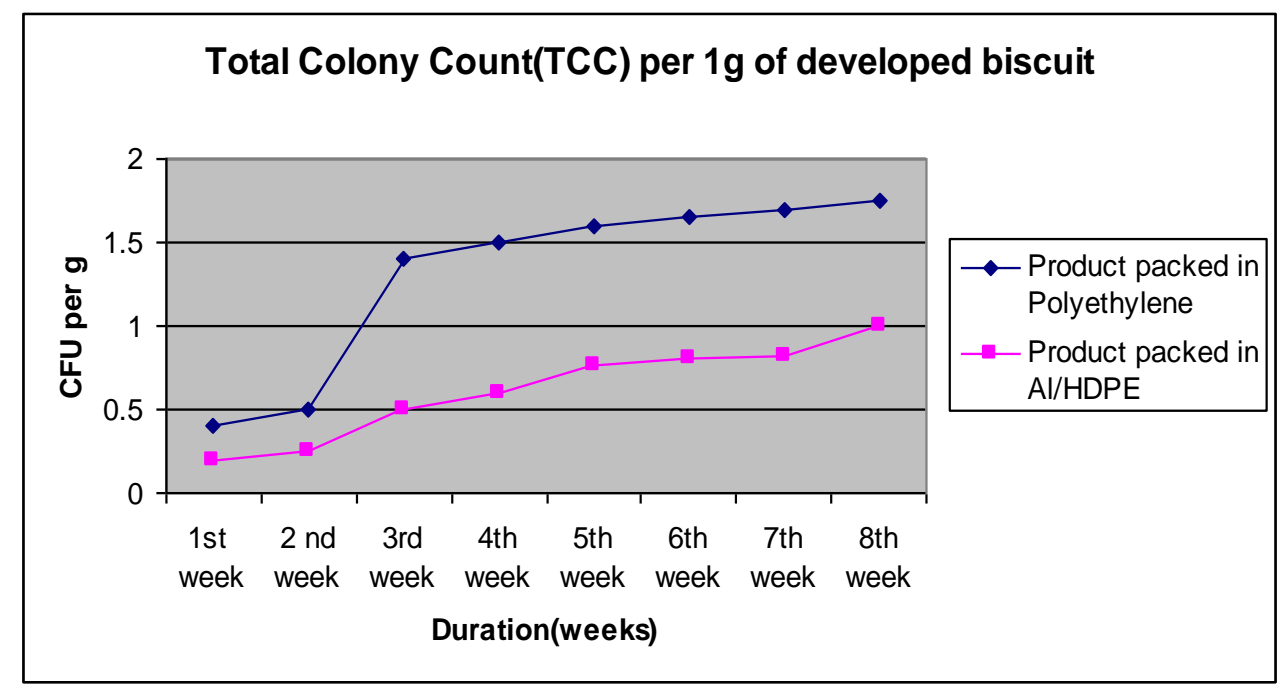

Figure 2 :Total colony forming units (CFU) per $1 \mathrm{~g}$ of developed product with the time 


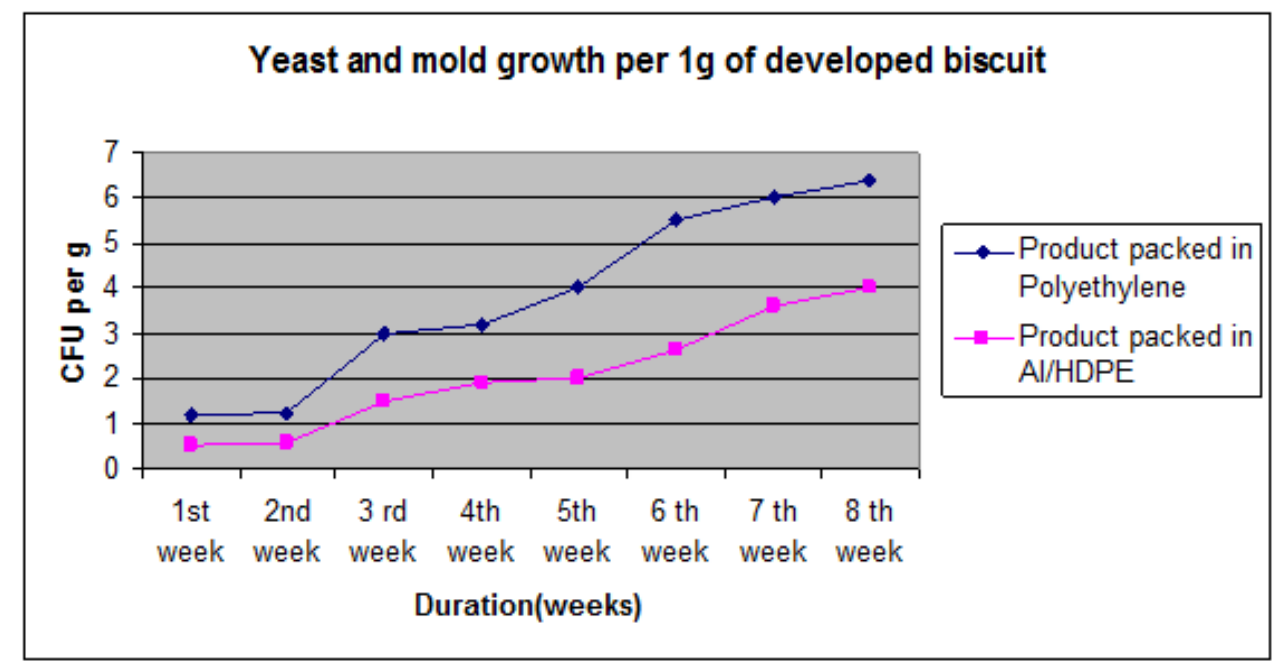

Figure 3:Total colony forming units (CFU) per $1 \mathrm{~g}$ of developed product with the time

Until $3^{\text {rd }}$ week growth rate of colony forming units are slightly increasing. But after the $3^{\text {rd }}$ week the Total colony count is rapidly increasing. Colony formation rate is comparatively high in product packed in polyethylene than product packed in Al/HDPE. The microbiological examination, in terms of Total Colony Count (TCC, CFU/g), ranged from 1.00 to 1.75.The counts were minimal and are within acceptable limits.

\section{Variation of Titrable acidity of the developed product with the shelf life}

According to Tritable acidity and yeast and mold count developed product has three weeks shelf life with any externally added preservatives. Yeast and mold are the prominent organisms for the shelf life reduction when compare with the bacteria. Due to the development of the acidic nature of the product yeast and mold growth rate is high. Yeast and mold growth rate is comparatively high in product packed in polyethylene than product packed in Al/HDPE.

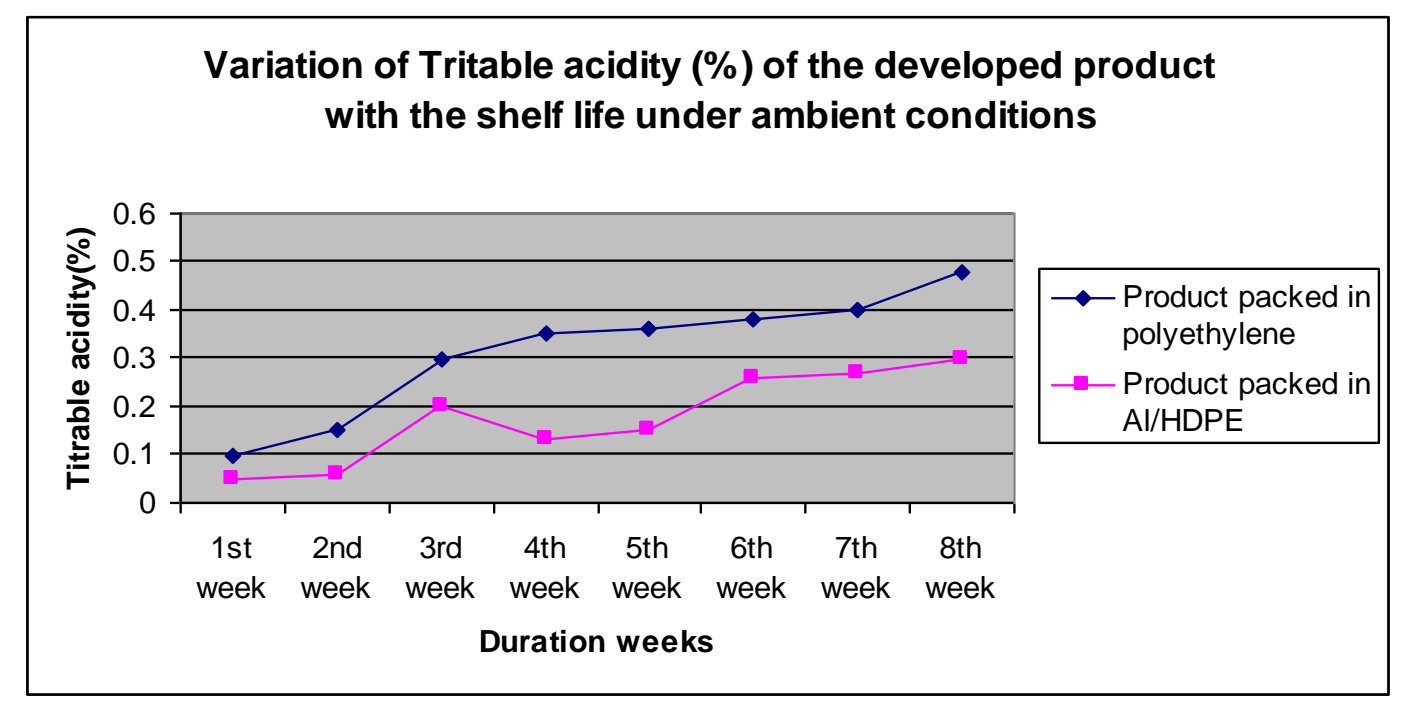

Figure 4: Variation of Titrable acidity of the developed product

As illustrated in Figure 4, after $3^{\text {rd }}$ week, Acid value of the product is increasing. The Tritable acidity of the product deviation indicates the deterioration which can occur by microbial activities and lipid oxidation (rancidity) like chemical reactions. 


\section{Moisture absorption capacity of banana blossom flour during Storage}

According to the Figure 5, moisture absorption capacity is increasing rapidly after third week. This will cause microbial contamination in the developed product. Moisture absorption capacity is comparatively high in product packed in polyethylene than product packed in $\mathrm{Al} / \mathrm{HDPE}$

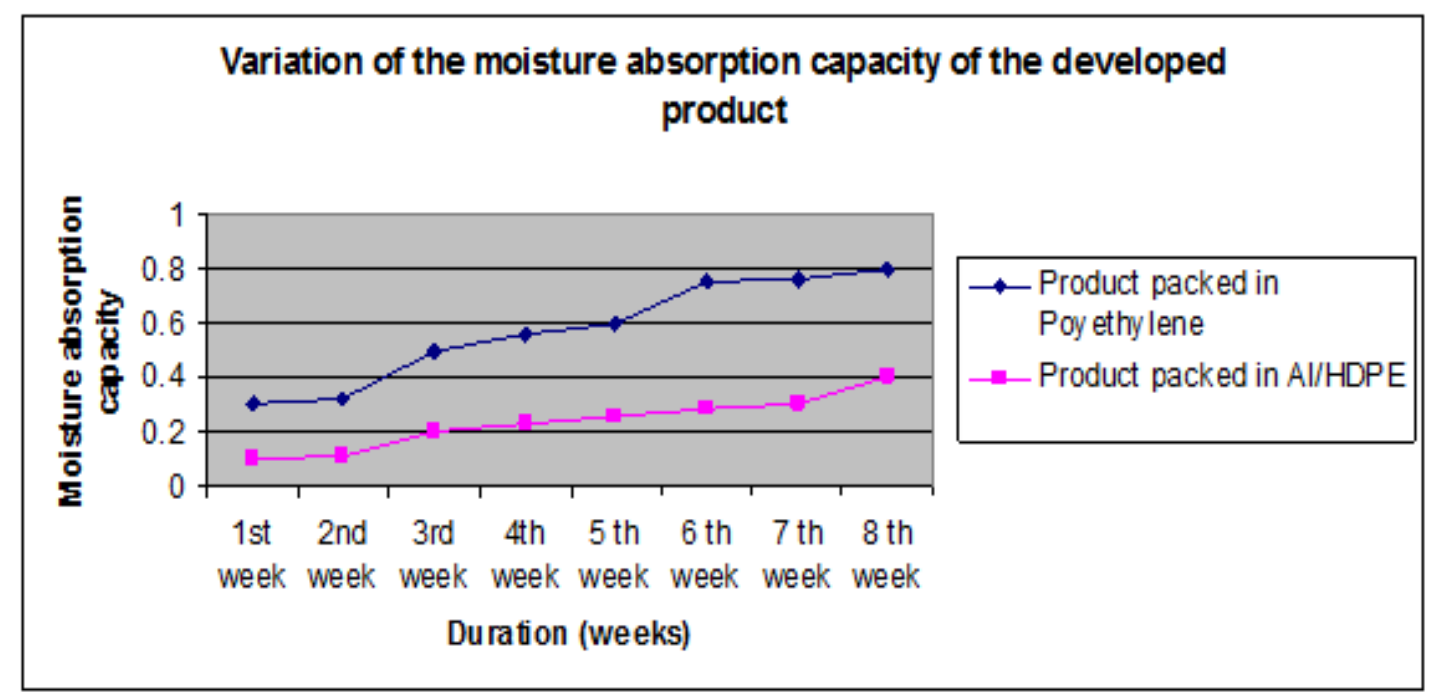

Figure 5: variation of the moisture absorption capacity of the developed product

\section{Sensory evaluation}

Sensory evaluation results of the best treatment for degree of Incorporation of banana blossom flour

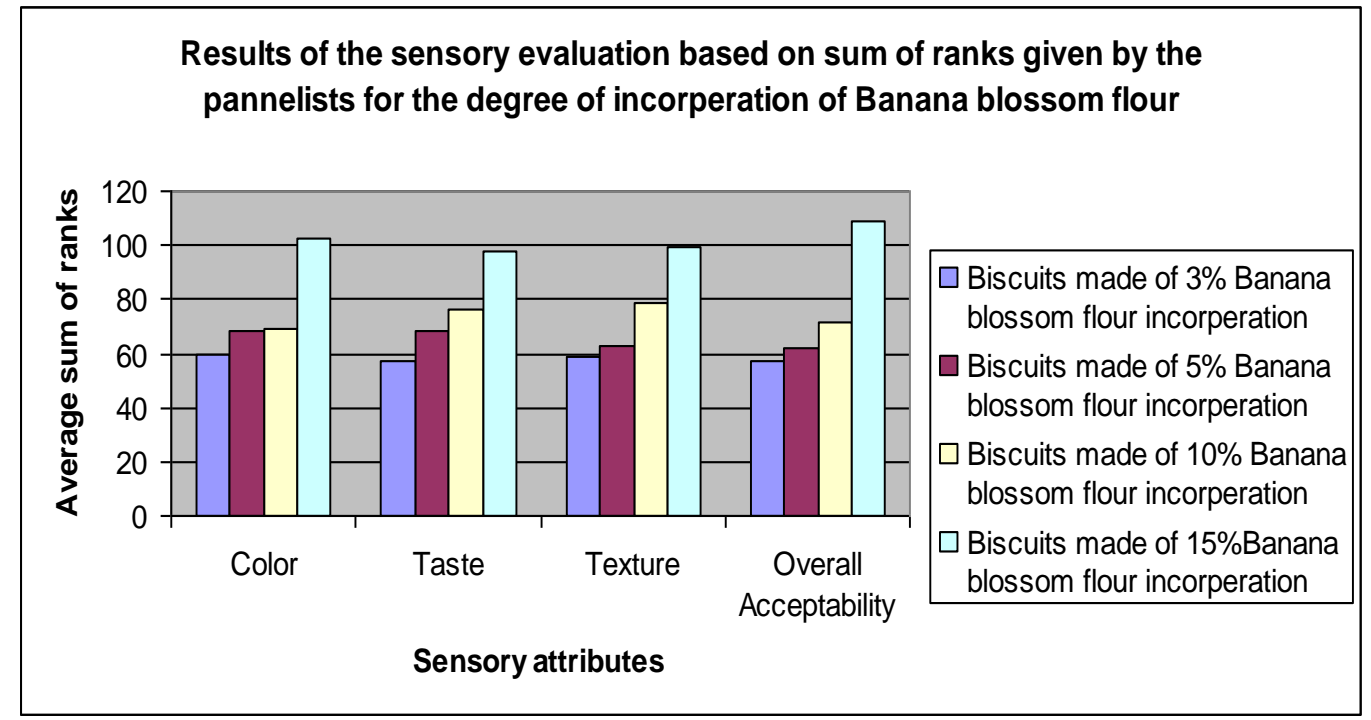

Figure 6: Results of the sensory evaluation based on the sum of ranks given by the pannelists for the degree of incorporation of Banana blossom flour

The results obtained in Figure 6, show high sensory ratings for all the selected attributes evaluated except sample biscuits made of $3 \%$ Banana blossom flour incorporation that scored the lowest. Comparing the biscuits made of incorporating 5\% and 10\% Banana blossom flour, it was observed that at 5\% significance level, there were no significant 
Differences in attributes of taste, flavor and color while $15 \%$ has a significant difference in terms of all sensory attributes.

\section{Sensory evaluation results of the best treatment for the type of Rice flour used}

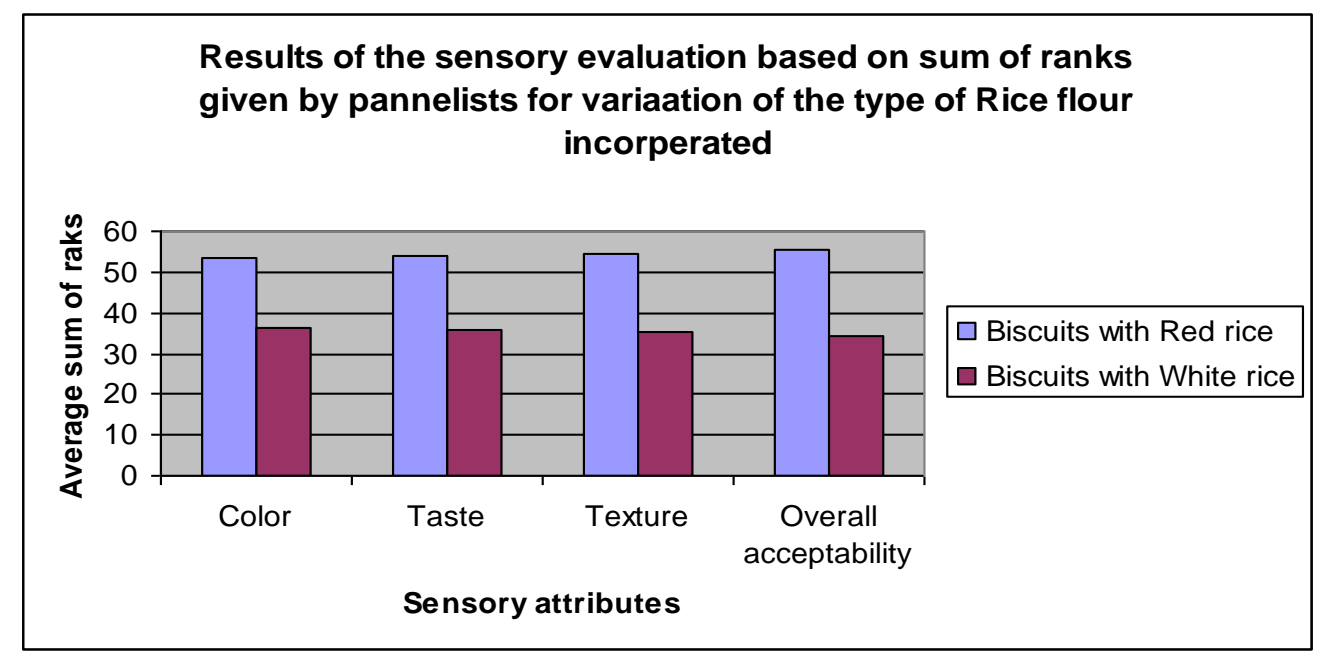

Figure 7: Results of the sensory evaluation based on the sum of ranks given by the panelists for the variation of the type of Rice flour incorporated

According to the Figure 7, Compared to the biscuits made of white rice flour incorporation of $15 \%$ Banana blossom flour the biscuits made of Red rice flour incorporation of 15\% Banana blossom flour has a significant difference at $5 \%$ significance level, for attributes such as taste, texture, color and overall acceptability.

Sensory evaluation results of the best treatment for the particle size Of the banana blossom flour and effect of the flavoring agent

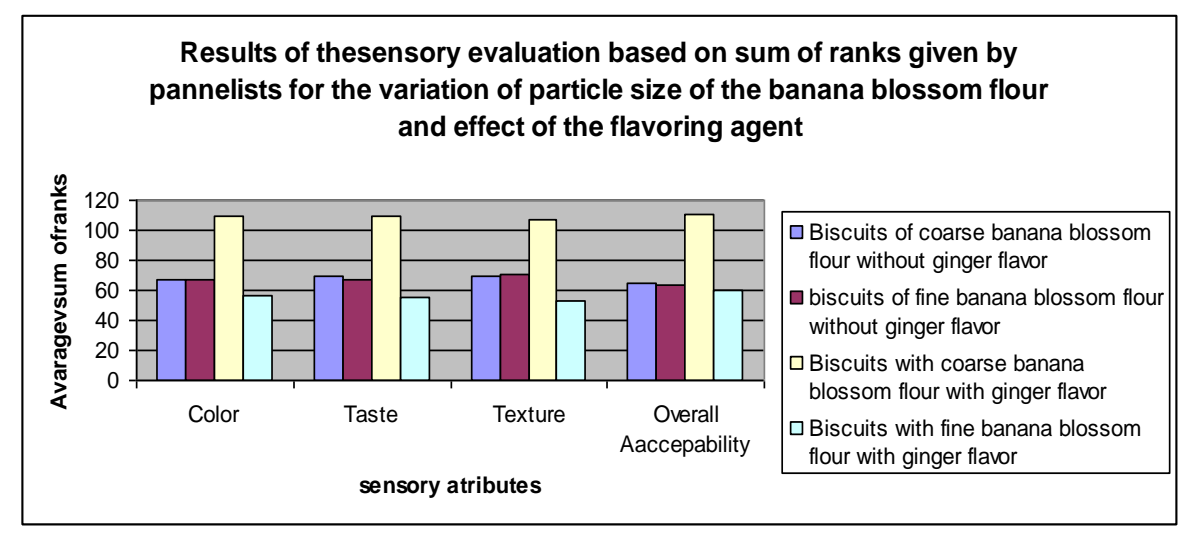

Figure 8: Results of the sensory evaluation based on the sum of ranks given by the panelists for the variation of the particle size of the banana blossom flour and effect of the flavoring agent

The results obtained in Table 3, show low scores for all the selected attributes evaluated except the biscuits made of coarse banana blossom flour with added ginger flavor that scored the highest. Comparing the other biscuits, it was observed that at $5 \%$ significance level, there was no significant difference in attributes of taste, texture, color and overall acceptability. 


\section{Conclusions}

Rice consumption among the Sri Lankan can be increased through the value addition. Because the value added products like rice biscuits increase the consumption of rice as supplementary food not only for adults but for children.

By developing a biscuit substituting Rice flour for wheat flour and enriching the product with banana blossom flour will promote the utilization of Banana blossom which is so far remain as an underutilized vegetable.

The developed product consists of high fiber content as expected and it is far above than what is already available in the market.

Table 3:Comparison of the fiber rich rice based biscuits with similar type of Biscuits

\begin{tabular}{|l|l|l|l|}
\hline $\begin{array}{l}\text { Parameter/ Sample of the biscuit } \\
(\%)\end{array}$ & $\begin{array}{l}\text { Karapincha Herbal } \\
\text { Biscuits }\end{array}$ & Bran Crackers & $\begin{array}{l}\text { Fiber rich Rice } \\
\text { based Biscuits }\end{array}$ \\
\hline Protein & 1.37 & & \\
\hline Ash & ND & 10.6 & 2.93 \\
\hline Moisture & ND & ND & 2.40 \\
\hline Fat & 1.86 & ND & 8.35 \\
\hline Fiber & 0.11 & 8.4 & 19 \\
\hline Carbohydrate & 11.18 & 6.2 & 12.32 \\
\hline
\end{tabular}

ND-Not determined

Economically feasible - Total production cost of biscuits are around three rupees per biscuit and it is also can be stored without any preservatives can store for 3-4 weeks.

Compatible with busy life style, in order to obtain a high nutritional value and it is a safe product to consume due to inapplicability of artificial ingredients.
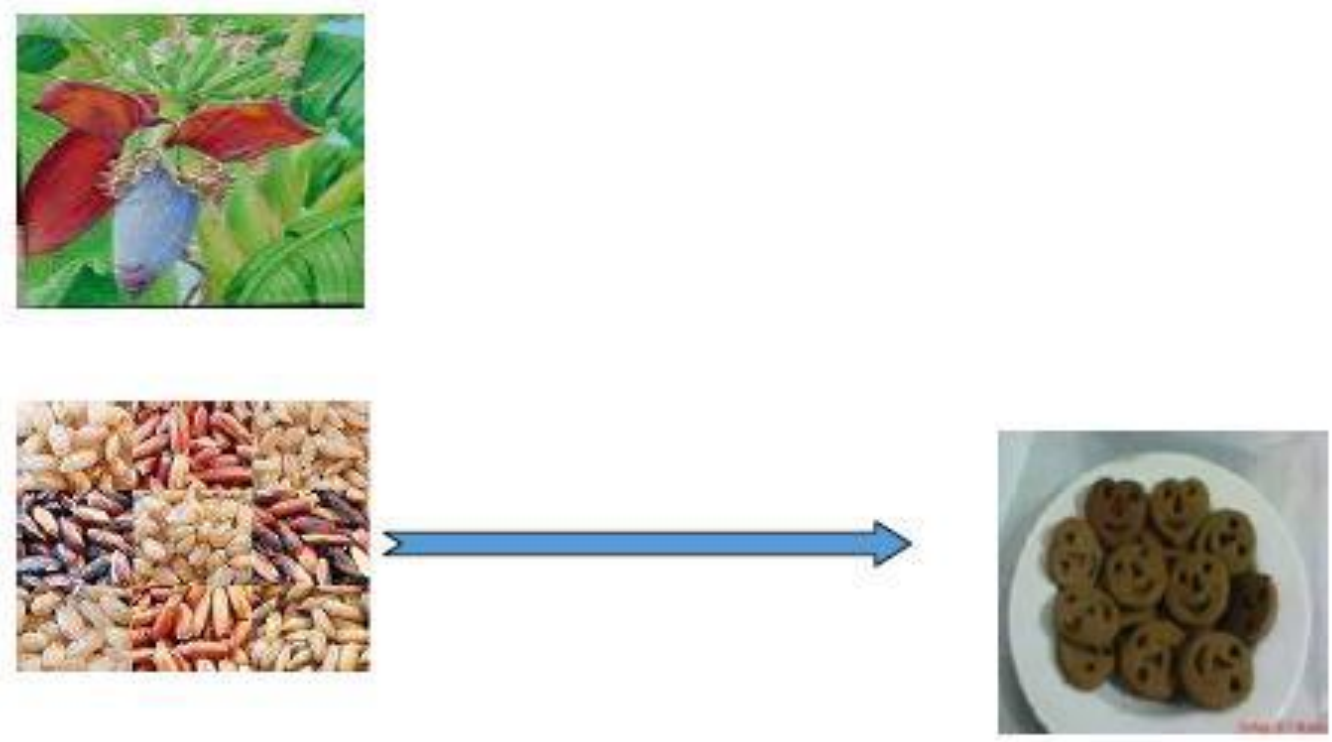

Figure 8: Development of Fiber rich rice based biscuit 


\section{References}

Manley,D.J.R.1998. Biscuits, Cookies and Cracker Manufacturing manuals

Woodhead Publishers Limited, England. P 4-67.

Manimegali, G. rammmah, S.1998. Effects of Pretratment on the quality characteristics of dehydrated bitter gourd rings, Indian Food Packer 52:7-11

Judith, A. M, McBurney M.I and Slavin, J.L. 2002, Health Implication of dietary Fiber Journal of American Dietatic Association 102 : 993-1000

Hand Book of SLS Standards, SLS: 516 part 1,2,3

Ranganna, S. 1986 . Hand book of Analysis of Quality control for Fruits and Vegetable, P 931

Wickramarachchi, K.S ranamukaarachchi S. L .2005 .Preservation of Fiber rich Banana Blossom as a dehydrated vegetable, Science Asia 31: 265-271

Wade, P. 1988 , Biscuits , Cookies and Crackers The principle craft 1: 1-4

Kure, O.A, Bahago , E.J, Daniel, E.A, 1998, Studies on the proximate composition and effect of flour particles size on acceptability of the biscuit produced from blends of Soybean and Plantain Flours. NumidaTech Scope 3: $17-21$

Kordylas , J.M 1990, Processing and Preservation of Tropical and Subtropical Foods, Macmillan Education Limited, London . P 34-39

Ihekoronye , A.1999. Manual on small scale food processing , $1^{\text {st }}$ edition, Academic Publishers , Nsukka, P. 32 